\title{
The AWful Taste of Partially Hydrogenated VEGETABLE OIL: A RECOMMENDATION THAT INDIANA BAN TRANS FATS FroM RESTAURANTS
}

Andrew J. VanLandingham ${ }^{*}$

I. INTRODUCTION 326

II. WHY CAN'T I JUST HAVE MY PARTIALLY HYDROGENATED

VEGETABLE OIL FRIED FRENCH FRIES IN PEACE?

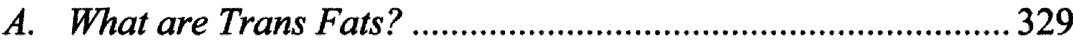

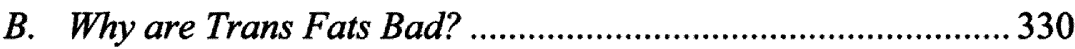

1. Physiological Effects on the Body ........................................330

2. The Unknown Danger.........................................................331

III. REMOVING TRANS FATS FROM AMERICA'S DIET ...........................332

A. Indiana's Current Approach to Trans Fat ................................333

1 Trans Fat Legislation ..........................................................333

2. Movements promoting a healthy lifestyle in Indiana .......... 334

B. New York City's Ban on Trans Fats..........................................335

1. Voluntarily Removal of Trans Fats fails in New York

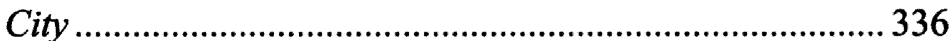

2. The Shift to a Mandatory Ban on Trans Fats ......................337

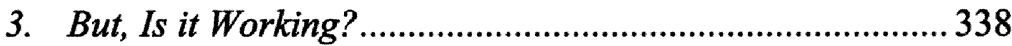

IV. GOVERNMENT AUTHORITY AND ITS LIMITS....................................338

A. Indiana's Authority to Regulate Food Establishments...............340

1. Curtice Bros. Co. v. Barnard...............................................341

2. Albert v. Milk Control Bd. ..................................................342

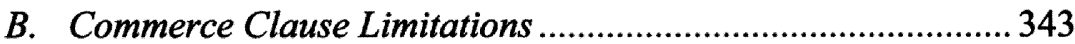

1. Dormant Commerce Clause Limitations ............................ 344

2. The FDA has not preempted state and local government bans on trans fats ........................................................................ 348

V. RECOMMENDATION THAT INDIANA REMOVES TRANS FATS FROM

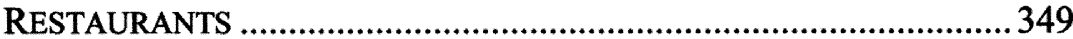

A. Public Health Regulatory Options .............................................. 349

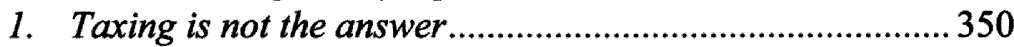

2. Altering physical and socio-economic environments is too costly and does not directly address the problem of trans

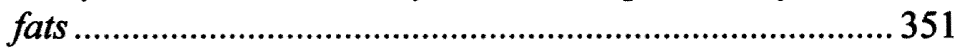

3. Litigation against Restaurants would not be effective........ 351

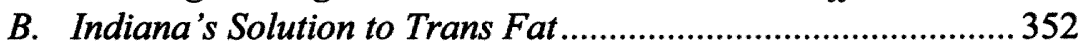

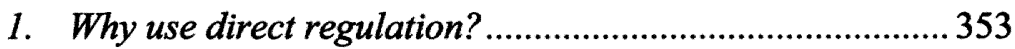

* J.D. Candidate, 2009, Indiana University School of Law - Indianapolis; B.A., 2006, Wabash College. 
2. The trans fat ban should be closely modeled after New York

City's ban ........................................................................ 354

VI. CONCLUSION 355

\section{INTRODUCTION}

One of the primary functions of federal and state government is to protect its citizenry. In the short span of a couple of months in 2008, the Food and Drug Administration ("FDA") hunted down potential food crops that may have caused an outbreak of salmonella, ${ }^{1}$ Congress passed amendments to the Foreign Intelligence Service Act to help prevent a terrorist attack on American soil, ${ }^{2}$ and municipal government in Los Angeles enacted a one-year moratorium on fastfood restaurants in impoverished areas of its city. ${ }^{3}$ Government responds to problems of all kinds, using broad police powers to validate action in the name of public safety. ${ }^{4}$ Often times, government response is more substantial when the public's health is put in immediate risk. ${ }^{5}$ An immediate and severe threat to our health gives government the broadest rationale for action. ${ }^{6}$

Yet, if a threat to public health is less immediate and more obscure, resistance to government action is much greater. Why should government hesitate to prevent risks that pose long-term threats to health? With emerging chronic disease epidemics, the inflation of health care costs, the desire to ensure the health and future of America's children, and providing healthier choices for America's food supply, the Indiana General Assembly should ban trans-isomer fatty acids ("trans fats") from all Indiana restaurants to ensure the long-term public health of its constituents. Undoubtedly, critics of a trans fat ban will argue that this form of public health legislation is a paternalistic or "nannystate" style of governance. To counter this argument, proponents of a trans fat ban must make a doubled-sided argument that is internally inconsistent. That is, proponents must highlight that removing trans fats from restaurants will provide a crucial public health benefit, while simultaneously emphasizing that

1. Annys Shin, All Tomatoes Cleared of Salmonella Risk, Officials Say, WASH. Post, July 18,2008 , at D01.

2. Dan Eggen and Paul Kane, Surveillance Bill Offers Protection To Telecom Firms, WASH. POST, June 20, 2008, at A01.

3. Lisa Baertiein, Los Angeles City Council passes fast-food ban, REUTERS, July 30, 2008, available at $\mathrm{http}: / / \mathrm{www}$. reuters.com/article/healthNews/idUSCOL06846020080730.

4. See generally Edward P. Richards, Public Health Law as Administrative Law: Example Lessons, 10 J. Health CARE L. \& Pol'Y 61, 64 (2007).

5. See generally Michael Greenberger, The Alfonse and Gaston of Governmental Response to National Public Health Emergencies: Lessons Learned from Hurricane Katrina for the Federal Government and the States, 58 ADMIN. L. REv. 611 (2006) (discussing the need for administrative procedure to improve coordination between federal and state governments during disasters).

6. Id. 
most Hoosiers will not notice that trans fat has been removed from their favorite restaurant foods.

The latter argument highlights the difficulty of passing public health legislation. If the government begins to regulate something that is seemingly obscure and benign, such as trans fats in restaurant food, critics will react with speculation and claim that there is too much government paternalism interfering with the free market. ${ }^{7}$ A trans fat ban conjures the image of Uncle Sam swatting the hand of a restaurant patron from that "oh-so-dangerous" French fry. This hypothetical imagery is an absurd scenario that nearly every American would reject.

The question, however, remains: what role should the government play when it comes to regulating the nation's diet? On one hand, there is an epidemic of chronic disease ravaging the country. ${ }^{8}$ Diabetes, heart disease, and even some cancers are more prevalent now than ever before. ${ }^{9}$ In addition to an unhealthier population, chronic disease is also burning a hole through American pocketbooks. The nation's weight problem causes "an estimated $\$ 69$ billion to $\$ 117$ billion" to be spent every year in obesity-related health problems. ${ }^{10} \mathrm{On}$ the other hand, there is fear that government regulation controlling what restaurants can serve will eventually lead to regulations that may control every aspect of an individual's diet, effectively eliminating free choice. ${ }^{11}$

Banning trans fats from restaurants, however, does not remove an existing choice granted to restaurant patrons. Generally, consumers cannot choose to avoid trans fats when eating at a restaurant mainly because restaurants are not statutorily required to post nutritional information. Thus, consumers are not privy to important ingredient information when selecting meals. Recently, however, several cities and states have tried enacting laws that require restaurants to display nutritional information in menus. ${ }^{12}$ Outside of those legislative

7. Roger S. Magnusson, Mapping the Scope and Opportunities for Public Health Law in Liberal Democracies, 35 J.L. MED \& ETHICS 571, 576 (2007).

8. See, e.g., NAT'L CTR. FOR HEALTH STATISTICS, DEP'T OF HEALTH AND HuMAN SERVICES, PUBL'N No. 2007-1232, HEALTH, UNITED STATES 3 (2007), available at http://www.cdc.gov/nchs/data/hus/hus07.pdf ("[I]ncreased longevity is accompanied by increased prevalence of chronic conditions and their associated pain and disability.").

9. Id. ("Of concern for all Americans is the high prevalence of people with unhealthy lifestyles and behaviors, such as insufficient exercise and overweight, which are risk factors for many chronic diseases and disabilities including heart disease, diabetes, hypertension, and back pain.").

10. Sarah Taylor Roller, Theodore Voorhees, Jr. \& Ashley K. Lunkenheimer, Obesity, Food Marketing and Consumer Litigation: Threat or Opportunity, 61 FOOD \& DRUG L.J. 419, 419 (2006).

11. See Nat'l Restaurant Ass'N., 2007 State Legislative Session Summary 5 (2007), available at http://www.restaurant.org/pdfs/government/07_state_legislative_summary.pdf ("The [National Restaurant Association] believes that if activists succeed in imposing trans-fat bans, they'll press for regulation of sodium and other ingredients. The Center for Science in the Public Interest has already talked about increased regulation for other foods and beverages, including wine, beer, soda, milk, coffee, sugar, artificial sweeteners, salt, oils and fats, olestra, poultry, meats and cheese.").

12. Id. at 4. (identifying all states and cities that have proposed, enacted, or have pending 
attempts, a patron generally must go to great lengths to determine whether they are eating trans fats. Typically, consumers are denied easy access to important nutritional information when eating at restaurants, and are therefore, ipso facto, denied choice. As more Americans eat outside of the home, it is a likely consequence that more trans fats will continue to be consumed, but not because consumers choose to do so. ${ }^{13}$ At home, Americans do have a choice. In 2003, the Food and Drug Administration ("FDA") amended its nutritional labeling requirements by mandating the disclosure of trans fat content on food labels. ${ }^{14}$ Consumers can now choose whether they want to purchase food that contains trans fat because the information is readily available. The result is a large control-gap between the ability to avoid trans fats at home (via mandated disclosure) and the inability to avoid trans fats while eating in a restaurant.

In light of the harmful consequences of trans fats and the appropriate remedial measures discussed above, this Note will examine the proper role government should take to curb consumption of harmful trans fats by the American population, with a specific focus on Indiana state government. Part II of this Note will discuss what trans fats are, how they entered into Americas' diet, and their adverse effects on the health of those who consume them. Part III will examine how various levels of government are regulating trans fats, with a close examination in Part III(a) on Indiana's current approach to trans fats and New York City's recent ban on trans fats. Part IV will examine the authority and limitations of government when regulating public health, including an analysis of Indiana food regulation cases and an analysis of potential Commerce Clause problems. Part V will examine the various governmental strategies to improve public health and proffer a conclusion as to which method is most persuasive for regulation of trans fats. Lastly, with respect to Indiana, this Note will conclude with the suggestion that the State adopt legislation banning trans fats from all restaurants in Indiana.

menu labeling legislation as of September 12, 2007). See also Ray Rivera, Battle Over CaloriePosting May Widen, N.Y. TimES, Sept. 13, 2007, available at http://www.nytimes.com/2007/ 09/13/nyregion/13calories.html.

13. ECON. RESEARCH SERV., AGRIC. INFO. BULLETIN No. 749, AWAY-From-Home-FoodS INCREASINGLY IMPORTANT TO QUALITY OF AMERICAN DIET 1 (1999), available at http://www.ers.usda.gov/publications/aib749/aib749.pdf("Over the past decades, eating out has been increasingly popular for Americans. In 1970, 26 percent of total food expenditure was spent away from home; by 1996 , that number had risen to 39 percent.").

14. FoOd AND DRUg ADMIN., FDA ACTS TO PROVIDE BetTer INFormation to CONSUMERS ON TRANS FATS 1 (2003), http://www.fda.gov/oc/initiatives/transfat/ (last visited Nov. 8, 2007) (estimating the mandatory requirement will prevent " 600 to 1,200 cases of coronary heart disease and 250 to 500 deaths each year" within three years of the enforcement date, [Jan. 1, 2006].”). 


\section{WHY CAN'T I JUST HAVE MY PARTIALLY HYDROGENATED VEGETABLE OIL FRIED FRENCH FRIES IN PEACE?}

\section{A. What are Trans Fats?}

Trans fat is the common moniker used to refer to a type "unsaturated fatty acids with at least one double bond in the trans configuration." fatty acids "are formed during the partial hydrogenation of vegetable oils, a process that converts vegetable oils into semisolid fats for use in margarines, commercial cooking, and manufacturing processes." 16 Some trans fats occur naturally "in meats and dairy products from cows, sheep, and other ruminants; these trans fats are produced by the action of bacteria in the ruminant stomach." 17 Data on the health effects of consuming these natural trans fats are limited. Consequently, the health effects of natural trans fats consumption remain relatively unknown when compared to artificial trans fats, ${ }^{18}$--the majority of trans fat intake in food prepared in or with hydrogenated vegetable oil. ${ }^{19}$

On the molecular level, trans fatty acids are close cousins of saturated fatty acids. ${ }^{20}$ Trans fatty acids derive their name from the double hydrogen bond that exists on the 18-carbon bond chain. ${ }^{21}$ The hydrogen bond exists on opposite sides of the chain and cause the typical fatty acid to straighten out and become more rigid. $^{22}$ The strong structure of a trans hydrogen bond provides a large amount of stability to the molecule; therefore, the fatty acids are less likely to break down when put under stress,such as heating. ${ }^{23}$ Thus, trans fatty acids are used in restaurants because they "have a long shelf life, their stability during deep-frying, and their semisolidity [sic] which can be customized to enhance the palatability of baked good and sweets." 24

In restaurants it is common to "cook and fry with partially hydrogenated oils. Trans fat is [also] found in many pre-fried, baked, and prepared foods served in restaurants." 25 Pre-fried foods are especially common in restaurants

15. Dariush Mozaffarian, Martijn B. Katan, Alberto Ascherio, Meir J. Stampfer \& Walter C. Willet, Trans Fatty Acids and Cardiovascular Disease, 354 NEw ENG. J. MED. 1601, 1601 (2006).

16. Id.

17. Id.

18. Id. at 1609 ("[T] he sum of the current evidence suggests that the public health implications of consuming trans fats from ruminant products are relatively limited.").

19. Id. at 1601 (highlighting that two to three percent of calories consumed in the American diet come from "industrially produced trans fatty acids" compared to a mere half percent of trans fatty acids consumed from natural origins).

20. See Rozenn N. Lemaitre et al., Cell Membrane Trans-Fatty Acids and the Risk of Primary Cardiac Arrest, 105 CIRCULATION 697, 697 (2002).

21. Mozaffarian, supra note 15, at 1601.

22. Id. at 1602 .

23. Robert Eckel et al., Understanding the Complexity of Trans Fatty Acid Reduction in the American Diet, 115 CIRCULATION 2231, 2233 (2007).

24. Mozaffarian, supra note 15 , at 1601.

25. N.Y.C DEP'T OF HEALTH AND MENTAL HygIENE, DOES YouR KITCHEN NEED AN OIL 
because they reduce cooking time significantly. It is no wonder, then, that these pre-fried foods also happen to be staples of the American diet, "such as French fries, fried chicken, chicken nuggets, fish fillets, chips, taco shells, and doughnuts."26 Most baked goods also contain high levels of trans fats due to the amount of shortening and margarine used in their production. ${ }^{27}$

\section{B. Why are Trans Fats Bad?}

When trans fats first hit the market in 1911 , the nutritional impact was unknown. ${ }^{28}$ It was not until the 1990's that researchers began to understand the effect of trans fats on the body. ${ }^{29}$ Now, more studies are being released on a consistent basis that adds to the growing list of illnesses that trans fats are linked to and/or cause. ${ }^{30}$ Unfortunately, because the effects of trans fats are just now being discovered, the public remains confused about the actual danger of trans fats and how to reduce trans fat consumption.

\section{Physiological Effects on the Body}

The major risk posed by trans fats is that they "raise low density lipoprotein (LDL or "bad") cholesterol in the blood. An elevated LDL cholesterol increases the risk of developing coronary heart disease (CHD)."31 Trans fat also lowers "HDL-C [high-density lipoprotein or "good" cholesterol] and impair[s] FMD [flowed-mediated vasodilation]. This suggests that [trans fats] increase the risk of CHD more than the intake of saturated fats, with similar effects on LDL cholesterol." 32

This increased risk of heart disease from trans fats has broad implications.

CHANGE? 2 (2005), available at $\mathrm{http}: / / \mathrm{www} . n y c . g o v / \mathrm{html} / \mathrm{doh} /$ downloads/pdf/cardio/cardiotransfat-brochure.pdf [hereinafter DOES YOUR KITCHEN NEED AN OIL CHANGE?].

26. Id. at 2. But see BanTransFats.com, Eateries News, http://www.bantransfats.com/ eateriesnews.html (last visited Mar. 5, 2008) (listing all major restaurant chains that have announced the removal of or have already removed trans fats from their menus).

27. See Nutrition Source- Fats and Cholesterol: Out with the Bad, In with the Good, http://www.hsph.harvard.edu/nutritionsource/what-should-you-eat/fats-full-story/index.html (last visited Sept. 8,2008 ) (Some margarine has as much as $23 \%$ of its total fat contributed to trans fats and shortening can have nearly $18 \%$ ).

28. Eckel et al., supra note 23, at 2232.

29. Id. (noting that in 1958 "researchers reported that within the context of a $35 \%$ butterfat diet, there was no significant difference between supplemental corn oil and hydrogenated corn oil.").

30. Id.

31. FDA and Center for Food Safety \& Applied Nutrition, Questions and Answers about Trans Fat Nutrition Labeling, http://www.cfsan.fda.gov/ dms/qatrans2.html\#s4q1 (last visited Mar. 5, 2008).

32. Nicole M. de Roos, Michiel L. Bots \& Martijn B. Katan, Replacement of Dietary Saturated Fatty Acids by Trans Fatty Acids Lowers Serum HDL Cholesterol and Impairs Endothelial Function in Healthy Men and Women, 21 ARTERIOSCLEROSIS, THROMBOSIS, AND VASCULAR BIOLOGY 1233, 1236 (July 2001), available at http://atvb.ahajournals.org/cgi/content /full/21/7/1233 (explaining that consumption of trans fat decreased HDL-C, but could not determine if the "impaired vasodilation was attributable to the decrease in HDL-C"). 
A medical review of several studies examining trans fat intake effects concluded "a 2 percent increase in energy intake from trans fatty acids was associated with a 23 percent increase in the incidence of CHD [coronary heart disease]." 33 This data, when extrapolated across the general population, means " 10 to 19 percent of CHD events in the United States could be averted by reducing the intake of trans fat." sumption of trans fats also increases the risk of primary cardiac arrest ("PCA"). This population study showed that increased trans fat consumption was "associated with a modest 1.5-fold increase in risk of PCA after adjustment for traditional risk factors." 35

\section{The Unknown Danger}

In May of 2003, San Francisco lawyer, Stephen Joseph, responded to these heightened dangers, and filed suit against $\mathrm{Kraft} / \mathrm{Nabisco}$ seeking an injunction to prevent the company from marketing its "Oreo" cookie to California children until the cookies contained no trans fats. ${ }^{36}$ His claim was based on the relatively little public knowledge of trans fats, and the dangers associated with their consumption: "[T] rans fat, is not commonly known to be unsafe. . . [t]hat's why trans fat is a far stronger case than tobacco or McDonald's because people know those are dangerous." 37 Joseph ultimately dropped the claim because the lawsuit had gained international attention, thus raising public awareness to the dangers of trans fats. ${ }^{38}$ In response to this exposure, $\mathrm{Kraft} / \mathrm{Nabisco}$ promised to rework the nutritional content of the Oreo and have since created a trans-fat free Oreo. $^{39}$

Despite similar suits, international media attention, governmental recommendations and nutritional labeling, the general public still remains confused and uneducated about the dangers of trans fats. A recent study conducted by the International Food Information Council revealed "[i]n general, fats are one of the more confusing labeling issues for consumers."

33. Mozaffarian, supra note 15 , at 1605 .

34. Id. at 1611 (stating that "[N] ear elimination of . . trans fats might avert between 72,000 (6 percent) and 228,000 (19 percent) CHD events each year.").

35. Lemaitre et al., supra note 20, at 699-700.

36. Kim Severson, Lawsuit seeks to ban sale of Oreos to children in California Nabisco taken to task over trans fat's effects, S.F. CHRON., May 12, 2003, at A3, available at http://www.sfgate.com/cgi-bin/article.cgi?f=/c/a/2003/05/12/OREO.TMP.

37. Id.

38. See Kim Severson, Maker of Oreos Promises Major Nutritional Overhaul, S.F. CHRON., July 2, 2003, at A1, available at http://www.sfgate.com/cgibin/article.cgi?f=/c/a/2003/0 7/02/OBESE.TMP; see also Carol Ness, Oreo is still King of the Chocolate Sandwich Cookies, S.F. CHron., June 21, 2006, at F2, available at http://www.sfgate.com/cgibin/article.cgi?f=/c/a/2006/06/21/FDG1FJGAKV1.DTL.

39. Id.

40. See International Food Information Council, Effective Communication of Dietary

Fats: An Exploration of Language 4 (2007), available at http://www.ific.org/research/upload/Fats-Language-Report-final.pdf. 
sumers could identify the fat information in nutritional labeling,

to a certain degree, consumers mistrust the information about fats, particularly trans fats, that they are getting on food packages. Some expressed skepticism about either the taste or health of foods made to be lower in fat content. Others felt that excluding trans fat meant that other less than healthy fats were used in their place. ${ }^{41}$

Despite some mistrust in nutritional information on labels, "[m]ost consumers indicated that they understand that saturated fats and trans fats are unhealthy., 42 Some consumers, however, still expressed confusion over why trans fat are unhealthy. One consumer stated, "Trans fat I really don't understand. I understand saturated fat, but I don't understand why, now they're saying, 'Oh now it's no trans fat,' and you're eating [fast food], is what I just saw. And so I don't understand that. (Chicago, Female)."

The American Heart Association performed a similar online study to measure consumer knowledge concerning trans fats, as well as their nutritional behaviors associated with trans fats. ${ }^{44}$ The survey found that nearly $84 \%$ of the respondents were aware of what trans fats were; "[h]owever[,] close to half of the respondents lacked understanding of the health effects of trans fats."45 The study also suggests that American eating habits at restaurants are already worse than at home: "[c]lose to half of the respondents reported 'never' or 'rarely' ordering a menu item marked as being 'healthy' in some way."46

Ignorance of trans fat and its negative health effects only fuels the dangers associated with its consumption. But even knowing what trans fats are, and the health risks therein, consumers still lack the tools necessary to avoid the foods that contain them, especially in restaurants where no nutritional information is posted. Not knowing how to avoid trans fats, combined with unhealthy eating habits associated with eating out, makes trans fats in restaurants particularly dangerous.

\section{REMOVING TRANS FATS FROM AMERICA'S DIET}

Late in 2006, New York City adopted a city-wide trans fat ban in all res-

41. Id. at 8 .

42. Id. at 9.

43. Id.

44. See Eckel, supra note 23, at 2232 (noting that the online survey was conducted "in the spring of 2006 with a sample of 1000 adults 18 to 65 years of age.").

45. Id. (Only $53 \%$ of respondents "answered 'increased risk of heart disease' to the question 'To the best of your knowledge, what effect, if any, do each of the following have on your risk of heart disease?"').

46. Id. at 2233 . 
taurants, ${ }^{47}$ a policy shift that gained a large amount of media attention. ${ }^{48}$ Since that highly publicized ban, numerous cities, counties, and states have proposed their own trans fat bans and several others have already passed laws modeled after New York City. ${ }^{49}$ Indiana has not yet followed the emerging trend of regulating trans fats and is lagging behind in providing educational information regarding the harmful effects.

\section{A. Indiana's Current Approach to Trans Fat}

\section{Trans Fat Legislation}

Currently, Indiana has neither passed nor proposed legislation addressing trans fats in restaurants. The only current legislation that even mentions trans fats is Indiana Code 20-26-9, the School Breakfast and Lunch Program regulation:

Sec. 19: "Food and beverage items sold to students; nutritional values"

(c) At least fifty percent $(50 \%)$ of the food items available for sale at a school or on school grounds must qualify as better choice foods and at least fifty percent $(50 \%)$ of the beverage items available for sale at a school or on school grounds must qualify as better choice beverages. Food and beverage items are subject to the following for purposes of this subsection:

(3) Food items that meet all the following standards are considered better choice foods:

47. Thomas J. Lueck and Kim Severson, New York Bans Most Trans Fats in Restaurants, N.Y. TimES, Dec. 6, 2006, at A1, available at http://www.nytimes.com/2006/12/06/ nyregion/06fat.html.

48. See Jocelyn Noveck, N.Y. City Bans Trans Fats at Eateries, SAN JosE MercuRY News, Dec. 6, 2006, at 8A; Annys Shin, Trans Fat Banned in N.Y. Eateries; City Health Board Cites Heart Risks, WASH. Post, Dec. 6, 2006; Katherine Hobson, Diet, Fitness \& Exercise; NYC Bans Trans Fats, U.S. NEWS \& WORLD REPORT, Dec. 5, 2006, available at http://health.usnews.com/usnews/health/articles/061205/5health.transfat.htm (doing a Google news search for "New York City Bans Trans Fats" produces 11,600 hits).

49. See Nat'l Restaurant Ass'N., 2007 State Legislative SesSion Summary 5 available at $\mathrm{http}: / / \mathrm{www}$. Restaurant.org/pdgs/government/07_state_legislative_summary.pdf (providing a detailed list of cities, counties, and states that have proposed or passed legislation as of Aug. 27, 2007). Recently, California became the only state to pass a trans fat restaurant ban. The state law regulates trans fats similar to New York City ban. See Daniel Shelton, Review of Selected 2008 California Legislation: Health and Safety: Chapter 207: California's Fight Against Trans Fats, 40 MCGEORGE L. REV. 426 (2008), for a summary analysis of California's ban. 
(A) Not more than thirty percent $(30 \%)$ of their total calories are from fat.

(B) Not more than ten percent $(10 \%)$ of their total calories are from saturated and trans fat. ${ }^{50}$

School lunches are currently the only form of foodstuffs regulated by the State government to reduce the amount of trans fat consumption. Interestingly, this regulation is seemingly at odds with the U.S. Department of Health and Human Services recommendation that saturated fat consumption be kept at $10 \%$ of the daily caloric intake and that trans fat "consumption [be] as low as possible." 51

\section{Movements promoting a healthy lifestyle in Indiana}

The most prevalent health movement in Indiana is Governor Mitch Daniels' initiative for an "INshape Indiana." 52 This voluntary program encourages Indiana citizens to create an online account that helps monitor exercise, weight loss, and nutrition. The website's nutritional information mainly consists of links to other nutritional information sites, ${ }^{53}$ and includes an on-going question and answer session with a nutritionist. ${ }^{54}$ This nutritionist provides relevant information about trans fats, but that information is buried throughout one hundred and seventeen questions listed on the website. ${ }^{55}$ As mentioned above, the links to nutrition websites provide important information. Unfortunately, that information has been identified as confusing to most consumers. ${ }^{56}$ Additionally, much of the information is tailored to meals and snacks that are prepared at home. No information concerning restaurant food exists on the website.

The Indiana Department of Health website lists information about several public health programs, including the aforementioned INshape Indiana program. ${ }^{57}$ Information about trans fat is included in a public notice about the "Subway Guy," a8 "National Nutrition Month" quiz, and a tip-of-the-month that suggests shoppers "[g]o easy on foods with trans fatty acids, found in many

50. IND. CODE $§ 20-26-9-19$ (2006) (emphasis added).

51. U.S. DeP'T of Health AND Human SeRV., U.S. DeP'T OF AGRIC., PUbl'N No. 232, DIETARY GUIDELINES FOR AMERICANS 30 (2005), available at http://www.health.gov/dietary guidelines/dga2005/document/pdf/DGA2005.pdf

52. INShape Indiana, http://www.in.gov/inshape/ (last visited Jan. 16, 2008).

53. INShape Indiana: Nutrition Home, http:/www.in.gov/inshape/2267.htm (last visited Jan. 16, 2008).

54. INShape Indiana: Ask the Nutritionist, http:/www.in.gov/inshape/2271.htm (last visited Jan. 16, 2008).

55. $I d$.

56. International Food Information Council, supra note 39, at 4.

57. Ind. State Dep't. of Health, http://www.state.in.us/isdh/ (last visited Jan. 16, 2008).

58. Press Release, Ind. State Dep't. of Health, Nutrition Article (Nov. 14, 2006), available at http://www.in.gov/isdh/files/NutritionArticleRX.pdf

59. Step Up To Nutrition \& Health, National Nutrition Month 2006 Nutrition Quiz, http://www.in.gov/isdh/programs/cnop/nutrition_month/2006_NNM_Quiz.pdf(last visited Jan. $16,2008)$. 
processed foods." ${ }^{60}$ The Indiana General Assembly also released a pamphlet promoting a healthy lifestyle for women that encourages women to "[c]hoose foods that are low in trans fat, saturated fat and cholesterol.",61

At a local level, the Marion County Health Department has failed to provide information concerning trans fats to the public. ${ }^{62}$ The website does include a fast food restaurant eating guide, entitled "Fast Food Switcheroo," that encourages individuals to eat smaller portions of the food offered or choose different menu items. ${ }^{63}$ This guide, however, recommends foods that are high in trans fat, without any mention of the dangers of trans fats. ${ }^{64}$

Indiana officials did make small steps when they chose to eliminate a traditional, local source of trans fat from the food landscape in 2008. The Indiana State Fair Advisory Committees removed trans fat from the oils used to cook food at the annual fair. ${ }^{65}$ This was a voluntary process, "in which [fair officials] spent the winter months testing various oils and, despite the fears of some concessionaires about possible changes to taste or costs or tradition, concluded that trans-fat-free oils created what Ms. Hoye [the Executive Director of the Indiana State Fair] called a better product." ${ }^{, 66}$ The State Fair Advisory Committee also noted the public attention that the Indiana State Fair received because of the trans fat policy adopted. ${ }^{67}$ The New York Times covered the trans fat ban on its front page, ${ }^{68}$ and several other state fairs nationwide- with momentum from Indiana - removed trans fats from their vendors. ${ }^{69}$

\section{B. New York City's Ban on Trans Fats}

New York City's highly publicized ban on trans fats was a monumental regulatory move. The ban affected nearly 25,000 food serving establishments

60. Ind. State Dep't. of Health, Nutrition Month Tip of the Day, available at http://www.in.gov/isdh/files/tip-of-the-day.pdf(listing the trans fat tip under the March 20, 2006 tip).

61. Indiana House of Representatives' Democratic Publications Office, Healthy Women, 4, available at $\mathrm{http}: / / \mathrm{www}$. in.gov/legislative/house_democrats/pdf/womenshealth_vanden burgh.pdf (last visited Nov. 7, 2007).

62. Marion Co. Health Dep't, Online, http://www.mchd.com/ (last visited Nov. 7, 2007).

63. Marion Co. Health Dep't., Fast Food Switcheroo, available at http://www.mchd. $\mathrm{com} / \mathrm{pdf} /$ fastfoodswitch.pdf (last visited Mar. 5, 2008).

64. See generally Burger King Nutritional Guide, http://www.bk.com/Nutrition/PDFs/ brochure.pdf (last visited Mar. 5, 2008) (The Marion County Health Department's Fast Food Switcheroo, supra note 62, offers Burger King's chicken tenders as a suitable replacement for a chicken sandwich. According to Burger King's nutrition guide the chicken tenders contain three grams of trans fat per serving.)

65. Monica Davey, Yes, Deep-Fried Oreos, but Not in Trans Fats, N.Y. Times, Aug. 21, 2007, at A1, available at $\mathrm{http} / / \mathrm{www}$.nytimes.com/2007/08/21/us/21 fat.html

66. Id.

67. StATE FAIR AdVISORY COMMITTEE, INTERIM COMMITTEE MEETING MINUTES, at 2 (Ind. 2007), available at $\mathrm{http} / / \mathrm{www}$.in.gov/legislative/interim/committee/minutes/SFACA9K.

68. Id.

69. See Davey, supra note 65, at A1; see also Kathryn Masterson, Fair Foods with Less Guilt? Some are Trans Fat Free, L.A. TIMES, Jul. 9, 2007, at F5. 
that have annual sales of around $\$ 11.3$ billion. ${ }^{70}$ In comparison, Indiana has approximately 11,000 food serving establishments statewide and generates about $\$ 8.3$ billion in sales. ${ }^{71}$

New York City's ban was the first large-scale food regulation based upon dietary information. The ban on trans fat was specifically implemented to improve the health of all New Yorkers. ${ }^{72}$ While the ban has drawn criticism, it has been widely imitated throughout the United States and the world. ${ }^{73}$ The importance of New York City's ban cannot be overlooked and must be analyzed to determine how the large-scale trans fat ban has been such a success.

\section{Voluntarily Removal of Trans Fats fails in New York City}

The first stage of New York City's ban, the "educational initiative," began in early August $2005{ }^{74}$ The goal of the educational initiative was to encourage "restaurateurs and food suppliers to voluntarily make an oil change by eliminating partially hydrogenated vegetable oils from the kitchen." 75 The New York City Department of Health and Mental Hygiene ("DOHMH") created the educational initiative in reaction to the FDA's recommendation that trans fat intake be kept as low as possible. ${ }^{76}$ Additionally, the DOHMH conducted a survey and found that " $30 \%$ of [New York City] restaurants used oils or fats known to contain partially hydrogenated vegetable oil for cooking or frying, or in spreads, such as margarine." 77

The educational initiative used several forms of media to spread information about trans fats and tips for how to "clear your kitchen of trans fats." DOHMH campaign's central tool was a mass letter and educational brochure

70. New York City Restaurant Association, New York City Restaurant Statistics, http://nysra.affiniscape.com/associations/2487/files/NYC\%20Statistics.pdf(last visited Feb. 12, 2008).

71. National Restaurant Association, Indiana Restaurant Industry at a Glance, http://www.restaurant.org/pdfs/research/state/indiana.pdf (last visited Feb. 12, 2008).

72. N.Y. COMP. CODES R. \& REGS. tit. 24, $\$ 81.08$, background (2007) (explaining that "[t]he public health concern addressed by this amendment is the presence of trans fat in foods served in restaurants, which represents a dangerous and entirely preventable health risk to restaurant goers. Yet New York City restaurant patrons currently have no practical way to avoid this harmful substance." Id.).

73. See BanTransFats.com, Ban Trans Fats: The Campaign to Ban Partially Hydrogenated Oils, http://www.bantransfat.com, (last visited Feb. 12, 2008) (Since New York enacted their trans fat ban, approximately, a combined forty cities, counties, states and foreign countries have either implemented trans fat bans or are in the process of doing so.)

74. Press Release, New York City Dep't of Health and Mental Hygiene, Health Department Ask Restaurateurs and Food Suppliers to Voluntarily make an Oil Change and Eliminate Artificial Trans Fat (Aug. 10, 2005), available at http:/www.nyc.gov/html/doh/html/pr/pr08305.shtml.

75. Id.

76. Id.

77. Id.

78. DOES Your KITCHEN NeEd AN OIL CHANGE?, supra note 25, at 1. 
sent to "20,000 restaurants and 14,000 supermarkets and food suppliers."79 Additional information was made available on the DOHMH's website and through a phone hot line. ${ }^{80}$ The campaign strategy is interesting because the DOHMH did not just spread information about the health dangers of trans fat, but it also focused on helping restaurants to identify what products contained trans fats and how to replace them. ${ }^{81}$ The DOHMH used a supportive and practical approach, as opposed to fear-based tactics designed to scare restaurants into trans fat replacement.

\section{The Shift to a Mandatory Ban on Trans Fats}

The educational initiative, however, was only backed by a voluntarily trans fat removal program. ${ }^{82}$ After one year, additional DOHMH surveys determined trans fat "use remained common and [did] not decline substantially despite the Trans Fat Education Campaign." "83 In response to the sluggish voluntary response to the educational campaign, the DOHMH enacted the mandatory trans fat ban. The DOHMH amended the New York City Health Code concerning Food Preparation and Enforcement to include: "No foods containing artificial trans fat, as defined in this section, shall be stored, distributed, held for service, used in preparation of any menu item or served in any food service establishment. ..."84 The regulation was a two-part ban that that also managed to take transition costs into consideration.

The first phase of enforcement began on July $1,2007 .{ }^{85}$ This limited the ban to "oils, shortenings and margarines containing artificial trans fat that are used for frying or in spreads." ${ }^{86}$ The second phase began on July 1, 2008 and affects "oils or shortenings used for deep frying of yeast dough or cake batter, and all other foods containing artificial trans fat." 2008 's interim was designed to give bakeries an additional year to develop methods to remove trans fat from their kitchens. ${ }^{88}$ There are limitations, as the ban only applies to food

79. Press Release, New York City Dep't of Health and Mental Hygiene, Health Department Ask Restaurateurs and Food Suppliers to Voluntarily make an Oil Change and Eliminate Artificial Trans Fat, supra note 74..

80. DOES YOUR KITCHEN NEED AN OIL CHANGE?, supra note 25, at 2.

81. Id.

82. See Press Release, New York City Dep't of Health and Mental Hygiene, Health Department Ask Restaurateurs and Food Suppliers to Voluntarily make an Oil Change and Eliminate Artificial Trans Fat, supra note 74.

83. N.Y. COMP. CODES R. \& REGS. tit. $24, \S 81.08$ (2007).

84. Id.

85. Id.

86. Id.

87. Id.

88. See Kim Severson, Trans Fat Claims Butter as a Victim, N.Y. TIMES, Mar. 7, 2007, available at http://www.nytimes.com/2007/03/07/dining/07tran.html. See also Baking Management, Problem: Lowering Trans-Fat, Saturated Fat Levels in Bakery Goods, http://bakingmanagement.bakery-net.com/article.php?WID=16055 (last visited Mar. 6, 2008) (discussing the difficulty that bakeries have in removing trans fats from their recipes). 
prepared in the kitchen of a restaurant and is inapplicable "to food served in the manufacturer's original, sealed packaging, such as a package of crackers or a bag of potato chips." 89

Inspection of restaurants for use of trans fats is now included in the normal restaurant inspection by the DOHMH. ${ }^{90}$ Restaurants are required to keep food labels for products until that product is completely used up. ${ }^{91}$ If inspectors discover food that contains more than 0.5 grams of trans fat per serving, the restaurant will be cited for violations. ${ }^{92}$ These violations, however, are not counted against restaurants' overall "inspection score." cally amount to fines, ranging from $\$ 200$ to $\$ 2000 .^{94}$ A three-month grace period where no fines were levied was included at the beginning of the first-phase of the ban. ${ }^{95}$

\section{But, Is it Working?}

At publication, the ban has been in full effect for a full two years. Reports claim that it has been effective in the elimination of trans fats from restaurants. In September of 2007, the DOHMH announced, "[s]ome $94 \%$ of the more than 3,300 restaurants inspected between July 1 and September 1 had switched to spreads and oils containing zero grams of artificial trans fat." 96 Another independent study conducted in August of 2007, however, revealed that three of the biggest fast food chains were still serving french fries with trans fat content that was nearly six times the allowable amount. ${ }^{97}$ More evidence will have to be collected to determine whether the trans fat ban is effective in removing a significant portion of trans fat from the diets of most New York City citizens. As of now, studies are suggesting contradictory answers.

\section{GOVERNMENT AUTHORITY AND ITS LIMITS}

Promoting public health is an essential function of the Government on all

89. N.Y.C Dep't of Health and Mental Hygiene, The Regulation to Phase OUt ARTIFICIAL TRANS FAT IN NEW YORK CITY FOOD SERVICE ESTABLISHMENTS 1 (2007), available at, http://home2.nyc.gov/html/doh/downloads/pdf/cardio/cardio-transfat-bro.pdf [hereinafter The Regulation to Phase OUt Trans Fat].

90. Id.

91. Id.

92. Id.

93. Id.

94. Id.

95. The Regulation to Phase Out Trans Fat, supra note 84.

96. Press Release, New York City Dep't of Health and Mental Hygiene, $94 \%$ of Inspected Restaurants in Compliance with First Phase of Trans Fat Regulation (Sept. 17, 2007), available at http://www.nyc.gov/html/doh/html/pr2007/pr080-07.shtml.

97. Sewell Chan, Want Some Trans Fats with Those Fries? N.Y. TIMES, Aug. 2, 2007, available at http://cityroom.blogs.nytimes.com/2007/08/02/want-some-trans-fats-with-thosefries 
levels and throughout American history: "[c]ities such as Boston and New York have regulated public health matters for longer than they have been part of the United States. ${ }^{98}$ Few dispute that the Government should be involved in public health regulation; rather it's the mechanics of implementing public health regulation that often causes disagreement. The idea of government in America is not based on a positive duty to act in support of its citizens. American government is, instead, based on the notion that " $[t]$ he Constitution ... imposes no affirmative obligation on the government to act, to provide services, or to protect." $"$ That ideology, alone, does not explain why society generally opposes new public health measures. Lawrence $O$. Gostin offers four possibilities as to why government action regarding public health is "politically and publicly unpopular:"100

(1) The rescue imperative - society is willing to spend money inordinately to save a life of a person with a name, face and history, but less so to save "statistical lives;" (2) The technological imperative - public health services are less appealing and salient than the high technology solutions of microbiology and genetics; (3) The invisibility of public health- when public health is working well (e.g., safe food, water, and products), its importance is taken for granted; and (4) The culture of individualism - society often values personal goods (individual responsibility, choice and satisfaction) over public goods (population health and safety). ${ }^{101}$

Even though public health regulations are an important element to ensuring the continuity of the country, Gostin's four possibilities highlight the ease to with which people can, and will, ignore and discredit the importance of public health and welfare. This theory may also provide a glimpse into the rationale behind why existing public health laws, such as helmet laws, seatbelt laws, and smoking bans, are often met with opposition in the form of litigation. ${ }^{102}$ While governmental mandates banning trans fats have so far been successful at the city and county level, opposition at the state level may increase due to any of these

98. Edward P. Richards, Public Health Law as Administrative Law: Example Lessons, 10 J. Health Care L. \& Pol'y 61, 64 (2007).

99. See Lawrence O. Gostin, Public Health Theory and Practice in the Constitutional Design, 11 Health Matrix: J. L. MED. 265, 268 (2001).

100. Lawrence O. Gostin, Health of the People: The Highest Law?, 32 J.L. MED \& ETHICS 509,509 (2004).

101. Id.

102. See D.A.B.E. v. City of Toledo, 393 F.3d 692 (6th Cir. 2005) (upholding a city's smoking ban in restaurants and bars); Abate of Georgia v. Georgia, 137. F. Supp. 2d 1349 (N.D. $\mathrm{Ga} 2001$ ) (upholding laws requiring motorcyclists to wear helmets); State v. Hartog, 440 N.W.2d 852 (lowa 1989) (upholding state law requiring motorists to wear seatbelts). 
four possibilities. Hence, it is imperative to look at other recent public health measures in Indiana to determine the level of opposition that could impede the Indiana General Assembly from implementing a trans fat ban.

Running contrary to the public opinion of health regulations is the large amount of deference courts generally give the Government when reviewing public health laws. Justice Harlan explained the need for this deference in the seminal case, Jacobson v. Massachusetts, as a balance between individual liberty and the need for public safety, since it is "a fundamental principle that 'persons and property are subjected to all kinds of restraints and burdens in order to secure the general comfort, health, and prosperity of the state..."103 The development of judicial standards from this foundation has created the legal atmosphere in which "[s]tates are generally free to provide greater protection than are required by the United States Constitution or individual state constitutions." 104 The high level of deference that states receive from courts indicates that any legal challenge to a state's trans fat ban will not be successful.

\section{A. Indiana's Authority to Regulate Food Establishments}

The regulatory authority behind Indiana's food establishment law is rooted in the traditional police powers of the state. ${ }^{105}$ Accordingly, the Indiana legislature is afforded a large amount of deference when regulating food for the welfare of its citizens:

[I] $\mathrm{f}$ the Legislature of Indiana in the reasonable exercise of its police power, and for the welfare of its citizens, condemns as an adulteration the use of benzoate of soda in the preparation of articles of food, then, in the absence of a general acceptance of the proposition by the scientific world that such is not the case, there can, as to that

103. Jacobson v. Massachusetts, 197 U.S. 11, 26 (1903) (citations omitted) (holding that the state did not violate the due process clause of the 14th Amendment by mandating vaccinations for its citizens). See also Williams v. Mayor of Baltimore, 289 U.S. 36 (1933) (citations omitted). The Williams Court further explained the reasoning behind the Jacobson standard:

It is not the function of a court to determine whether the public policy that finds expression in legislation of this order is well or ill conceived. The judicial function is exhausted with the discovery that the relation between means and end is not wholly vain and fanciful, an illusory pretense. Within the field where men of reason may reasonably differ, the Legislature must Id. at 42 . have its way.

104. Edward P. Richards, Public Health Law as Administrative Law: Example Lessons, 10 J. HEALTH CARE L. \& POL'Y 61, 88 (2007).

105. See Albert v. Milk Control Bd, 200 N.E. 688, 691 (Ind. 1936) (explaining that the police powers of the State generally allow the legislature to regulate the milk industry to ensure milk "for human consumption be wholesome and healthful."). 
matter, arise no question of the violation of the Constitution of the United States, or, as here charged, of the state of Indiana. When deemed necessary by the Legislature for the public health, property rights such as here involved must give way. ${ }^{106}$

Due to the large amount of deference given to the State, restaurants are heavily regulated in Indiana. Most of the regulations were originally adopted to meet the standards of the Uniform Federal Drug and Cosmetic Act ${ }^{107}$ and to "safeguard the public health."108 Additionally, the Indiana Code gives the State Department of Health power to establish rules "for the efficient enforcement" of the sanitary requirements for restaurants. ${ }^{109}$ Restaurateurs must comply with the extensive and detailed list of regulations established by the administrative code. $^{110}$ Each provision of this list was implemented underneath the umbrella of public health.

Indiana case law reviewing the authority of the State to promulgate regulations is dated and fairly limited. The cases, however, provide the basis for future regulatory schemes that are an inherent part of the State's police power.

\section{Curtice Bros. Co. v. Barnard}

Curtice Brothers v. Barnard, a decision by the Seventh Circuit Court of Appeals, challenged an Indiana law that banned the use and sale of soda benzoate and subsequently gave authority to criminally prosecute those who sold it. ${ }^{11}$ The plaintiffs/appellants challenged the law under several legal theories, most notably the Fourteenth Amendment of the Federal Constitution. ${ }^{112}$ The law challenged was a broad regulation that prevented the use of additives in food unless the State Board of Health had previously approved them. ${ }^{113}$

The Fourteenth Amendment challenge required the court to apply a balancing test between the interests of the individual and the State's interest in

106. Curtice Bros. Co. v. Barnard, 209 F. 589, 593-94 (7th Cir. 1913) (holding that Indiana's ban on using benzoate of soda in food preparation is constitutional because there is no evidence that directly contradicts the reasonable findings of the state legislature). See also Wallace v. Feehan, 190 N.E. 438, 442 (Ind. 1934) (explaining that "whatever constitutes a real menace to such supply may be legitimately declared by statute to be a public nuisance.") (quoting Bowman v. Virginia State Entomologist, 105 S.E. 141, 145 (Va. 1920)).

107. 21 U.S.C. $\$ 301(1938)$.

108. IND. CODE § 16-42-1-1 (2006).

109. IND. CODE § 16-42-5-5 (2006) (giving authority to the state department based on IND. CODE. § 4-22-2).

110. See generally 410 IND. ADMIN. CoDE 7-24 (2008) (Under "Sanitary Standards for the Operation of Retail Food Establishments," Rule 24 of the Indiana Administrative Code lists nearly 450 separate regulations, including employee hand washing, shellstock condition, and the proper method for drying mops.)

111. Curtice, 209 F. at 589.

112. Id. (citing U.S. CoNST. amend. XIV).

113. Id. 
promoting public health. ${ }^{114}$ The court held the law constitutional because the State of Indiana was reasonably applying its police powers when it created the law. ${ }^{115}$ The court found that the individual interest companies had in using soda benzoate was weaker than the interest in promoting the public welfare of Indiana citizens. In issuing such a holding, the court applied a "reasonable basis" test in analyzing the law while giving a great deal of deference to the legislature. $^{116}$

The appellants' complaint argued that the Indiana Constitution prohibited the application of the State Board of Health law because it allowed officials "to distinguish as between harmless preservatives, permitting the use of some and prohibiting the use of others arbitrarily." "117 The court rejected this interpretation and determined that the statute limited the State Board of Health "to ascertain and declare what is a harmless preservative, and that it is not authorized thereby to exclude the use of any preservative which it finds to be harmless."118 The court found that the law did not grant arbitrary power to the State Board of Health and upheld the law. ${ }^{119}$ Despite its age, Curtice remains a key case because of the role deference was given with respect to the legislature and its scientific findings. The court admitted that the scientific community had not yet come to a consensus as to whether soda benzoate was harmful. ${ }^{120}$ The uncertainty surrounding the hazards of using soda benzoate, however, did not impair the legislature from regulating its use. ${ }^{121}$ Thus, it was the burden of the appellant, and not the State, to prove that soda benzoate was safe and not the State to prove it was harmful. ${ }^{122}$ The court's ruling established a large base from which the legislature is allowed to regulate food. Even without certain scientific evidence, the legislature is allowed to regulate food because the State has such an invested interest in the public health.

\section{Albert v. Milk Control Bd.}

In 1935, Indiana passed the Milk Control Act, ${ }^{123}$ due to an "emergency concerning the production and distribution of milk."

114. Id. at 593 (citing State v. Layton, 61 S.W. 171, 177 (Mo. 1901)).

115. Id.

116. Id. at 594 (stating that if the Indiana General Assembly engaged in a "reasonable exercise of its police power ... for the welfare of its citizens" to enact a law the court would not hold it unconstitutional.) (emphasis added).

117. Curtice, 209 F. at 594.

118. Id.

119. Id.

120. Id. at 592 (" $[\mathrm{I}] \mathrm{t}$ is evident that the question of the harmfulness and harmlessness of benzoate of soda is, as yet, an open one in the scientific world.").

121. $I d$.

122. Id.

123. The Milk Control Act, ch. 281, 1935 Ind. Acts 1365 (hereinafter the "Milk Control Act").

124. Albert v. Milk Control Bd., 200 N.E. 688, 690 (Ind. 1936) (citing the Milk Control 
Control Board (the "Board") to regulate quality of milk production and ensure price stability. ${ }^{125}$ The Board had the authority to issue penalties to those who violated the emergency provisions. ${ }^{126}$ The plaintiffs in Albert appealed a penalty imposed for "engag[ing] in the business of milk dealer, processer, distributorproducer, and distributing broker of milk without paying the license fee imposed, and without obtaining a license."

The plaintiffs' chief complaint challenged the constitutionality of the Milk Control Act underneath Article 1, section 1 of the Indiana Constitution, arguing the Act violated their "Natural Rights." 128 The court analyzed the constitutional challenge on the basis of the state's police power, reasoning "[i]f the act in question properly comes within the police power of the state, then it is not in violation of said article and section."129 The court determined that Indiana was properly exercising its police powers over milk considering the long-standing history of state-based milk regulation, accompanied by the fact that nearly every other state also regulated milk. ${ }^{130}$ The court held that the state could properly exercise its police power "to require that milk for human consumption be wholesome and healthful.",131

The court also juxtaposed the rights of the individual compared to the rights of the public at large. ${ }^{132}$ The individual right invoked by the plaintiffs was trumped by the public's right, "through the Legislature, to regulate [milk] for the benefit of the common interest of all." 133 The public's interest was based on milk's "direct relation to public health and the general welfare of the people." "134 As a result of this public interest, the plaintiffs had to conform their business practices to meet the standards and license qualifications set forth by the State. ${ }^{135}$

The Albert opinion sets the bar for state regulation of the food supply and may possibly be interpreted as superseding any individual interest-so long as the State is regulating under the scope of the traditional police powers and the matter being regulated has a connection to health and welfare of the public.

\section{B. Commerce Clause Limitations}

A statewide ban on trans fats raises a potential conflict between federal authority and state police powers underneath the Commerce Clause. ${ }^{136}$ There

Act).

125. The Milk Control Act, ch 281.

126. Id.

127. Albert, 200 N.E. at 689.

128. Id. at 690 .

129. Id.

130. Id.

131. Id.

132. Albert, 200 N.E. at 691.

133. Id.

134. $I d$.

135. Id.

136. U.S. ConsT. art. I, § 8, cl. 3 
are two potential ways a state-enacted trans fat ban may not survive a Commerce Clause challenge: if it is found in violation of the Dormant Commerce Clause or if federal preemption in the field of regulating trans fats already exists. A state regulation that places restrictions on businesses that are intertwined with the national stream of commerce could be challenged underneath the Dormant Commerce Clause theory. ${ }^{137}$ A countless number of national restaurant chains exist all over the state of Indiana and local restaurants often receive supplies from a national distributor. A statewide ban on trans fats places a kink in the national commercial activity of the restaurant business. Suppliers for all Indiana restaurants would have to tailor any Indiana deliveries to meet the standards imposed by a trans fat ban. The Commerce Clause, however, does not preclude all state regulation. ${ }^{138}$ It is likely that as long as the trans fat ban was applied evenly to all restaurants, whether local or national in character, a Commerce Clause challenge would fail. ${ }^{139}$

A statewide trans fat ban also raises federal preemption concerns because the federal government has enacted regulation concerning trans fat. On July 9, 2003 the FDA enacted a new food labeling regulation that required food manufactures to include information about the trans fat content of all labeled foods. ${ }^{140}$ The Nutrition Labeling of Food rule, ${ }^{141}$ requires that any foods with more than 0.5 grams of trans fat include the number of grams of trans fat on the nutrition label. ${ }^{142}$ This rule is the only federal action that regulates anything related to trans fat. The FDA's action is limited to nutritional labeling and does not preempt state action from regulating trans fats with other measures.

\section{Dormant Commerce Clause Limitations}

The Commerce Clause authority has well-established standards "framed upon the theory that the peoples of the several states must sink or swim together, and that in the long run prosperity and salvation are in union and not division." 143 It is well-known that the Commerce Clause provides Congress a large amount of discretion "to regulate Commerce. . . among the several states."144 The goal of the Commerce Clause and its broad grant of Congressional power

137. See generally BLACK's LAW DICTIONARY (8th ed. 2004) ("Dormant Commerce Clause. The constitutional principle that the Commerce Clause prevents state regulation of interstate commercial activity even when Congress has not acted under its Commerce Clause power to regulate that activity.").

138. See generally 15 C.J.S. Commerce $\S 14$ (2008).

139. Id.

140. Press Release, Dep't of Health and Human Services, HHS to Require Food Labels to Include Trans Fat Contents (July 9, 2003) available at http://www.hhs.gov/news/press/ 2003pres/20030709.html.

141. Nutrition Labeling of Food, 21 C.F.R. $\$ 101.9$ (2006).

142. Id. at $101.9(\mathrm{c})(2)(\mathrm{ii})$.

143. Gov't Suppliers Consolidating Services, Inc. v. Bayh, 753 F.Supp. 739, 763 (S.D. Ind. 1990) (quoting Baldwin v. G.A.F. Seeling, Inc., 294 U.S. 511,523 (1935)).

144. U.S. CoNST. art. I, $\S 8$, cl. 3. 
is at odds with the purposes of a state's inherent police powers. ${ }^{145}$ In particular, the Dormant Commerce Clause doctrine restricts the states' ability to regulate even in the absence of federal regulation. ${ }^{146}$ A state enacting regulations to protect their citizens must pass one of two tests. If a state regulation is facially discriminatory or discriminatory in its effect "the burden falls on the State to justify [the regulation] both in terms of the local benefits flowing from the statute and the unavailability of nondiscriminatory alternatives adequate to preserve the local interests at stake."147 The second test, derived from Pike $v$. Bruce Church, Inc., ${ }^{148}$ applies to state regulations that are applied "evenhandedly to effectuate a legitimate local public interest, and its effects on interstate commerce are only incidental ..." 149 The Pike test only invalidates a state regulation if its application imposes a burden that is "clearly excessive in relation to the putative local benefits."

It is unlikely that a court would apply the first test to a trans fat ban. ${ }^{151} \mathrm{~A}$ correctly written trans fat ban would not be facially discriminatory because it would theoretically apply to both local and national restaurants. Nor would a trans fat ban be discriminatory in effect because both local and national restaurant chains would have similar burdens to modify their operations. ${ }^{152}$ Thus, courts would likely use the Pike test to determine whether a trans fat ban violates the Dormant Commerce Clause.

The Pike test is designed to balance the burden and the benefit of a state regulation to determine if the regulation is actually worth the costs it imposes. ${ }^{153}$ As already noted, a trans fat ban would apply evenhandedly to all restaurants in Indiana. There may, however, be a question of whether the burden of a trans fat ban is too heavy in comparison to the benefits it provides. ${ }^{154}$

This ban would no doubt be a regulation designed to promote the health

145. See generally Elizabeth Young Spivey, Trans Fat: Can New York Save its Citizens From this "Metabolic Poison?", 42 GA. L. REV. 273, 294 (2007).

146. See BlACK's LAW DiCTIONARY, supra note 137.

147. Hunt v. Wash. Apple Adver. Comm'n, 432 U.S. 333, 353 (1977) (citations omitted) (holding North Carolina's apple grading statute was unconstitutional because its discriminatory effect on interstate commerce was economic protectionism).

148. Pike v. Bruce Church, Inc., 397 U.S. 137 (1970).

149. Id. at 142 (citations omitted) (holding that an Arizona law regulating the packing of agriculture products was unconstitutional despite its evenhanded application because it was too heavy of a burden on interstate commerce).

150. Id.

151. See Hunt, 432 U.S. at 353 (citing the first test of the Dormant Commerce Clause).

152. See Spivey, supra note 145, at 297-302, for an analysis of New York City's trans fat ban using the Commerce Clause test for regulations that are facially or effectively discriminatory.

153. See generally James D. Fox, State Benefits Under the Pike Balancing Test of the Dormant Commerce Clause: Putative or Actual?, 1 AVE MARIA L. REV. 175, 176 (2003)(discussing the practical, but chaotic, effect of evaluating state benefits underneath the $P$ ike balancing test).

154. U.S. v. Lopez, 514 U.S. 549, 580 (1995) (J. Kennedy concurring) ("Distinguishing between regulations that do place an undue burden on interstate commerce and regulations that do not depends upon delicate judgments"). 
of the public. Typically, courts give broad discretion to public health and safety laws when applying analyses of the Dormant Commerce Clause. ${ }^{155}$ However, no bright line test exists to clearly define when a burden becomes so heavy it outweighs the interests of public health and safety. ${ }^{156}$ The Supreme Court has upheld public health and safety laws such as a state regulation requiring imported meat be disease-free certified, ${ }^{157}$ a statewide ban on the sale of milk in plastic containers, ${ }^{158}$ and a waste flow control ordinance that significantly increases recycling. ${ }^{159}$ The Court's analysis in these cases focused on the benefits that these regulations provided, with little discussion on the burdens imposed. ${ }^{160}$ On the other end of the Pike balancing test, the Court has invalidated a state law that limited truck length on local highways ${ }^{161}$ and a state law that required trucks to use a specific style of mudguards. ${ }^{162}$ In both cases, the Court used a cost-benefit method of analysis to determine whether the burden imposed on interstate commerce was too high. ${ }^{163}$

If the Court determines a state regulation provided a substantial or vital benefit to the public's health or safety, it is unlikely to overturn the regulation no matter how burdensome the regulation may be. ${ }^{164}$ Conversely, if the Court finds that the state regulation is not very beneficial, even a minimal burden may invalidate the state regulation. ${ }^{165}$ Thus, it is important for the State to emphas-

155. See Wendy E. Parmet, After September 11: Rethinking Public Health Federalism, 30 J.L. MED \& ETHICS 201, 202-03 (2002).

156. See generally Fox, supra note 153 , at 177 (discussing the practical effect of evaluating state benefits underneath the Pike balancing test).

157. Mintz v. Barber, 289 U.S. 346 (1933) (upholding the regulation because it allowed other states to certify meat without placing a complete ban on out-of-state meat).

158. Minn. v. Clover Leaf Creamery Co., 449 U.S. 456 (1981) (upholding a Minnesota ban on plastic milk jug containers because the regulation was designed to increase resource conservation).

159. United Haulers Ass'n, Inc. v. Oneida-Herkimer Solid Waste Mgmt. Auth., 127 S.Ct. 1786 (2007) (upholding a New York solid waste regulation that required all trash be routed through a locally owned facility because it increased recycling).

160. See Mintz, 289 U.S. at 359 (reasoning that the meat certification "was promulgated in good faith and is appropriate for the prevention of further spread of the disease among dairy cattle and to safeguard public health. It cannot be maintained therefore that the order so unnecessarily burdens interstate transportation as to contravene the commerce clause").

161. Kassel v. Consol. Freightways Corp., 450 U.S. 662 (1981) (holding that Iowa's ban on trucks longer than sixty feet imposed a burden on interstate commerce that outweighed any public safety the ban provided).

162. Bibb v. Navajo Freight Lines, Inc., 359 U.S. 520 (1959) (holding that Illinois' curved mudguard requirement did not provide a substantial public safety benefit to justify the large burden on interstate commerce).

163. C.f. id. at 525-27 (The Bibb Court asserted that cost of the safety regulation is not the only tool of analysis. The Court also examined the delay that the regulations could impose on interstate truck traffic. Delay in commercial traffic, however, is another way of analyzing the cost of the Illinois regulation because 'time is money.')

164. See generally Fox, supra note 153 , at 178 (stating that "[T] he state benefits analysis is often the determinative factor in Pike cases.").

165. See generally id. at 208-209. (discussing how courts have interpreted the Pike test and the subsequent result of unpredictable decision because courts have not applied the test consistently.) 
ize the benefit of a public health regulation. Courts are more likely to presume the regulation is valid if the benefits are substantial, rather than trying to attempt to minimize the burdens. The latter argument is less likely to be successful.

In the context of trans fats, it is likely that a court would hold that the benefit of the ban outweighs the burden. Several studies have shown a dramatic increase in coronary heart disease is connected to just a small increase in consumption of trans fats. ${ }^{166}$ Removing trans fats could potentially save the lives of thousands of Hoosiers every year. ${ }^{167}$ A statewide trans fat ban would also raise awareness about the dangers of eating trans fats and encourage healthier eating habits. These benefits, however, are somewhat speculative. While studies have proven the dangers of trans fats, eliminating them from restaurants will not completely remove trans fats from American diets. ${ }^{168}$ The health benefits of banning trans fats in restaurants could be nullified if individuals begin consuming more at home. This is an unlikely scenario because more and more food manufacturers are removing trans fats from their products. ${ }^{169}$ Nonetheless, removing trans fats completely from a major source of Indiana citizens' diets is a legitimate and important public health interest of the state that could help save and improve lives.

The burden imposed by a trans fat ban is not oppressive. It forces private business owners to switch from products containing trans fats, but this is typically an easy and low cost move. ${ }^{170}$ Additionally, several alternative products exist that easily replace trans fats in the kitchen, giving more flexibility to restaurant owners to decide how to remove trans fats. ${ }^{171}$ Furthermore, some law and economic experts have crudely analyzed the cost-benefit of a trans fat ban and have determined the New York City ban is benefit positive. ${ }^{172}$ It is possible

166. See Mozaffarian, supra note 15 , at 1605.

167. See InD. STATE DEP'T OF HEALTH, INDIANA MORTALITY RATES - 2006 (2008), available at http://www.in.gov/isdh/reports/mortality/2006/table04/tbl04_00.htm\#IDX18. Approximately 48,500 Indiana residents died of heart related disease in 2006. According to Mozaffarian, supra note 15 at 1611 , removing trans fats could prevent six to nineteen percent of CHD deaths each year. Extrapolated over the Indiana mortality data for 2006, removing trans fats could potentially save 2,900 to 9,200 lives.

168. See FDA Acts to Provide BetTer Information to Consumers on Trans Fats, supra note 14 (explaining that food manufactures only have to identify trans fat content of food if it has over .5 grams of trans fat per serving. Therefore, it is possible that food could have .49 grams of trans fat, but be identified as having no trans fats.).

169. See BanTransFats.com, Trans Fat News, http://www.bantransfats.com/transfatnews. html (last visited Mar. 6, 2008), for a list of major food products that have removed trans fats.

170. See generally BanTransFats.com, Ban Trans Fats: The Campaign to Ban Partially Hydrogenated Oils, http://www.bantransfats.com/index.html (last visited Mar. 6, 2008), for a comparison of prices between partially hydrogenated vegetable oil and trans fat free oils.

171. See id. for a list of suppliers who sell trans fat free oils.

172. See generally The Beckner-Posner Blog: The New York City Ban on Trans Fats, http://www.becker-posner-blog.com/archives/2006/12/the_new_york_ci.html (last visited Oct. 24,2008 ) (analyzing the New York City trans fat ban based on the estimated reduction of heart attack deaths in New York City and the rough cost of implementing the ban by the New York City restaurant industry.) 
that a trans fat ban could cause disruptions in the food distribution industry as restaurants shift to healthier oils, but no major problems have been reported since New York City enacted its ban. The economic impact that a trans fat ban in Indiana would have on interstate commerce is beyond the scope of this Note, but it is likely that any burden would be temporary. ${ }^{173}$

An Indiana ban on trans fat is likely to pass a Dormant Commerce Clause challenge. Not only would a trans fat ban not discriminate against interstate commerce, it would also provide a substantial public health benefit to all Indiana residents.

\section{The FDA has not preempted state and local government bans on trans fats}

Preemption of state action can occur when the federal government acts expressly to do so or through implied action. ${ }^{174}$ Generally, food regulation is a joint venture between state and federal governments. ${ }^{175}$ Regulation of domestic food is a traditional state police power. ${ }^{176}$ Therefore, preemption of a state trans fat ban only occurs if the federal government has enacted regulations specifically addressing trans fats.

The only federal regulation addressing trans fats is 21 C.F.R $\S 101.9 .^{177}$ Section 101.9 does not expressly preempt state action to regulate trans fats in general because the express preemption provision in Section 403A of the $\mathrm{Na}$ tional Uniform Nutritional Labeling Act only limits state action with regard to food labeling standards. ${ }^{178}$ Therefore, $\$ 101.9$ can only preempt state action if it does so implicitly.

Implied preemption may happen if federal action is so complete that it "[occupies an] entire field of regulation and has thereby 'left no room for states to supplement' federal law... [if] compliance with both state and federal law is impossible ... or [if] state law 'stands as an obstacle to the accomplishment and execution of the full purposes and objectives of Congress." 179 A potential statewide trans fat ban and $\S 101.9$ do not fall underneath any of the categories of implied preemption. While $\S 101.9$ expressly preempts states from regulating food nutritional labels, it does not completely encompass regulatory authori-

173. See id. (providing a rough estimate of the cost-benefit of the New York City Ban).

174. See generally Pac. Gas and Elec. Co v. State Energy Res. Conservation \& Dev. Com'n, 461 U.S. 190, 203-04 (1983).

175. See generally Wendy Aguilar, The Lowest Common Denominator: National Uniformity for Food Act, 16 SAN JOAQUIN AGRIC. L. REV. 57 (2006-2007) (discussing the history of domestic food regulation in the United States).

176. $I d$. at 61

177. Nutrition Labeling of Food, 21 C.F.R. $\S 101.9$ (2006).

178. See generally National Uniform Nutrition Labeling $\S 403,21$ U.S.C $\S 343-1$ (2000) (Section 343-1 governs all labeling requirements such 21 C.F.R $\S 101.9$, therefore all express preemptive provisions of 21 U.S.C $\S 343-1$ apply to $\S 101.9$ ).

179. Capital Cities Cable, Inc. v. Crisp, 467 U.S. 691, 699 (1984) (citations omitted). 
ty over the content of food generally or the use of trans fats specifically. thermore, a trans fat ban does nothing to make complying with $\S 101.9$ impossible. A trans fat ban regulates food preparation and in no way interferes with federal labeling requirements. Similarly, a trans fat ban would do nothing to hinder the Congressional purpose behind $\S 101.9 .^{180}$ Additionally, the FDA has determined that $\S 101.9$ only preempts state action "from imposing any nutritional labeling requirements for trans fat that are not identical to those required by this rule."181

Thus, a statewide trans fat ban does not have potential conflicts with any other federal regulation. Unless the federal government enacts regulations in the future with regard to trans fats, a statewide trans fat ban will be a proper exercise of a state's traditional police powers.

\section{RECOMMENDATION THAT INDIANA REMOVES TRANS FATS FROM RESTAURANTS}

Indiana has an opportunity to help improve the health of Hoosiers significantly without drastically increasing the state budget or entering uninvited into the personal habits of its citizens. The proper legal authority exists to take action; the only barrier that remains is public opinion. As discussed previously, overcoming the four common oppositions to public support for public health action tends to be the highest hurdle to clear. ${ }^{182}$ Choosing the right method for policy implementation can help combat those obstacles.

\section{A. Public Health Regulatory Options}

The Government's job to promote health on the public scale is a difficult balancing act, with "complex tradeoffs between individual and collected interest."183 Lawrence Gostin argues that government has "at least seven different models for legal intervention designed to prevent injury, and disease, encourage healthful behaviors, and generally promote the public's health."184 The seven models are: (1) General tax powers, (2) Information Campaigns, (3) Altering physical living environments, (4) Altering Socio-Economic Environment, (5) Direct Regulation, (6) Tort System, (7) Deregulation. ${ }^{185}$ Each option allocates

180. See Food Labeling: Trans Fatty Acids in Nutritional Labeling, Nutrient Content Claims and Health Claims, 68 Fed. Reg. 41,434, 41,437-38 (July 11, 2003) (codified at 21 C.F.R. $\S 101.9$ ) (The FDA's purpose for requiring trans fat to be labeled is to provide consumers with the information needed to make healthy choices in food selection. Removing trans fats from restaurants creates healthier choices for consumers, thus not conflicting with Congress' objective.)

181. Id. at 41,498 .

182. Gostin, supra note 100 , at 509.

183. Id. at 511

184. Id.

185. Id. at 511-513. 
burdens in a variety of ways, allowing for different problems to be met with answers that fit closely to the issues at hand.

Regulating trans fats in restaurants presents a unique intersection of individual and business interests. Any law passed by Indiana attempting to regulate Hoosier's diets would face the challenge of either of the two main legal hurdles to any public health law. ${ }^{186}$ The law, however, would also affect business operations and food preparation methods in restaurants. ${ }^{187}$ Any legislative action will likely produce strong opposition from restaurant owners based on the "culture of individualism." is crucial to choose the appropriate method of action to maximize health benefits while generating support for a bill that may be perceived as personally and commercially intrusive. Any legislation adopted should focus on meeting both of these broad goals.

\section{Taxing is not the answer}

The typical government model of "impos[ing] excise taxes in order to reduce the demand for 'demerit goods' that are harmful to health [such as] (tobacco)" would be hard to apply to trans fats. ${ }^{189}$ Tobacco is a distinct product that is taxed separately when it is sold to consumers to reduce demand. ${ }^{190}$ Taxing trans fats, however, would be difficult because they are just one ingredient out of several ingredients found in most food products. Therefore, the effect of reducing demand may be watered down because the tax on trans fat is perceived as a tax on food in general, and not just on one distinct harmful product.

Other questions arise as to how a tax such as this should be applied in food establishments. Should a restaurant have to a pay a tax on food that is prefried in oil that contains trans fats? Should food with more trans fat be taxed higher or should there be a flat tax for all foods with trans fats? Should food that is taxed be easily identifiable or should it just cost more without any identification? Any new taxation presents challenges in how it should be implemented. These specific concerns surrounding a trans fat tax, however, present large roadblocks to the ultimate goal of any trans fat legislation: eliminating its consumption. Adding an additional $5 \%$ or even $20 \%$ tax on food with trans fats seems futile. If french fries that normally cost $\$ 1.00$ are increased to $\$ 1.05$ or $\$ 1.20$, would that really stop consumption? A tax would have to substantially increase the price of a trans fat food item for it to be an effective deterrence.

186. See supra Part IV.B.

187. See BanTransFats.com, The Campaign to Ban Partially Hydrogenated Oils, $\mathrm{http} / / / \mathrm{www}$. bantransfats.com/index.html (last visited Feb. 12, 2008), for a discussion of the most prevalent critiques against a trans fat ban.

188. Gostin, supra note 100, at 509. (defining the "culture of individualism [as the fact that] society often values personal goods (individual responsibility, choice, and satisfaction) over public goods (population health and safety)." Id.).

189. Magnusson, supra note 7 , at 576.

190. Id. 
Increasing taxes or adding a new tax is typically politically unpopular. Garnering support from constituents and other members of a legislative body may prove to be difficult. ${ }^{191}$

\section{Altering physical and socio-economic environments is too costly and} does not directly address the problem of trans fats

Regulations adopted under these methods are hard to tailor specifically to the problem of trans fats. Laws made and enforced to alter physical and socioeconomic environments enact large-scale projects that are expensive and time consuming. ${ }^{192}$ Changing the layout of a city neighborhood or using zoning laws to provide a better opportunity for individuals to lead healthy lifestyles serve as a good long-term solution to America's health problem. ${ }^{193}$ These policies, however, do not provide a direct solution to the problem of trans fats. Using this form of health regulation would be an ineffective way to limit exposure to trans fats because the results can be gradual, indirect, and expensive.

\section{Litigation against Restaurants would not be effective}

Litigation against major food manufactures for the use of trans fats has been effective. ${ }^{194}$. Most of the lawsuits, however, have been based on hiding the ball from the public, or misleading the public into thinking that trans fats had been eliminated. ${ }^{195}$ Although these lawsuits have led several large food manufacturers to remove trans fats from their products, ${ }^{196}$ initiating litigation to remove trans fats from restaurants may be inefficient and ineffective.

Restaurants have already secured protection from obesity lawsuits. Individuals who attempted to sue McDonalds began to have success in obesitybased lawsuits. ${ }^{197}$ In response, several states, including Indiana, have passed a "Cheeseburger bill," which prohibits individuals from suing restaurants on the basis that the restaurants made them obese. ${ }^{198}$ Indiana's "Cheeseburger Bill"

191. The recent discussion involving a food and beverage tax increase to help support Indianapolis's Capital Improvement Board emphasizes the difficulty of getting a new food tax passed in Indiana. The plan to increase food and beverage tax was removed from the plan due to pressure from the public and the restaurant industry. See Mary Beth Schneider, CIB Plan met with Jeers, INDIANAPOLIS STAR, Apr. 3, 2009, at A1.

192. See Gostin, supra note 100, at 512 (discussing how the Government can alter the build environment to improve public health).

193. Id.

194. Molly Selvin, Lawyer Who Took On Oreos and McDonald's Fights On in Food War, L.A. TIMES, Sept. 25, 2005, at C1.

195. Amended Complaint for Injunctive Relief at 7, Bantransfats.com vs. Kraft Foods North America, No. CV 032041 (dismissed May 1, 2003) (on file with author).

196. See supra notes 36-39.

197. Tom Becker \& David Glovin, McDonald's Must Face Claim that Its Food Caused Obesity, Panel Rules, WASH. Post, Jan. 26, 2005, at E10.

198. See generally, David Burnett, Fast-Food Lawsuits and the Cheeseburger Bill: Critiquing Congress's Response to the Obesity Epidemic, 14 VA. J. Soc. PoL'Y. \& L. 357 (2007). See 
specifically grants immunity to food establishments from civil liability arising from a claim concerning:

(1) weight gain;

(2) obesity;

(3) a health condition associated with weight gain or ob-

esity; or

(4) a generally known condition:

(A) allegedly caused by; or

(B) allegedly likely to result from;

the long term consumption of food or beverages. ${ }^{199}$

The "Cheeseburger Bill" likely eliminates any chance that an individual could actually bring a lawsuit against a restaurant for causing heart disease related to the consumption of trans fats. Heart conditions would likely fall under the heading of a "generally known condition." There is, however, a potential argument that it is not generally known that long-term consumption of trans fats causes heart disease. ${ }^{200}$

Even if a trans fat lawsuit against a food establishment was allowed, the chances of winning a tort-based claim against a restaurant for causing an individual's heart problems are extremely low. How could an individual prove a restaurant serving trans fats was the most significant cause of a single cardiac disease event? Would the individual's genetic history come into play? Did the individual choose healthy items off the menu? There are numerous other significant variables that come into play when trying to connect an individual's consumption of trans fats to heart disease. This is not to say that this type of litigation would never be possible, but using the tort system is not the most efficient or effective way to remove trans fats from a restaurant's kitchen.

\section{B. Indiana's Solution to Trans Fat}

Indiana's approach to trans fat should be a combination of both an information campaign and direct regulation. Using both strategies maximizes the benefit that the public can receive from a trans fat ban. New York City's ban of trans fats serves as an effective model to exemplify the steps Indiana must take. For instance, New York City's informational campaign and year-long volunteer removal program did not have a major impact in decreasing trans fat use in restaurants; ${ }^{201}$ however, the campaign did help educate and inform New York city

also IND. CODE § 34-30-23-2 (2007), IND. CODE § 34-30-23-3 (2007)

199. IND. CODE § 34-30-23-3 (2006).

200. The strength of this argument, however, has not been tested yet because no one has challenged the "Cheeseburger Bill" or brought a suit against a restaurant for causing an unknown condition.

201. See discussion supra Part III.B.1-2. 
residents about the dangers of trans fats. ${ }^{202}$ The year-long campaign, however, did place trans fat awareness at the forefront of media attention and exposed the public to valuable health information. ${ }^{203}$ Indiana legislators must craft legislation that both limits Hoosier's exposure to trans fats in restaurants and also educates citizens to help them make healthy choices at home.

\section{Why use direct regulation?}

Use of direct regulation to address public health issues can be controversial. Several "[i]nfluential economic theories (e.g. laissez-faire and, more recently, a market economy) favor open competition and the undeterred entrepreneur."204 Regulation is often seen as an impediment to a flourishing market economy because it limits the freedom of the individual. This is the very notion of which Lochner v. New York was based. ${ }^{205}$ The Lochner Court used the Due Process Clause of the Fourteenth Amendment in an attempt to protect the individual's freedom to contract. ${ }^{206}$ The same economically conservative Supreme Court, however, also authored the opinion in Jacobson. ${ }^{207}$ Even in a time when the Court was tepid about government regulations potentially limiting individual freedoms, public health was exempt from a tougher level of scrutiny. ${ }^{208}$ That exception has grown over the years and regulatory action directly related to public health has been given wide latitude by the American judicial system. ${ }^{209}$ Indiana courts have also given wide latitude to the State when regulating food for the public health. ${ }^{210}$ It is clear that the Indiana General Assembly has the legal authority to enact a statewide ban of trans fats in restaurants. ${ }^{21}$ Additionally, any subsequent legal challenge would likely fail due to the large amount of deference that courts traditionally give states when the regulation concerns the state's traditional police powers.

202. Id.

203. Id.

204. Gostin, supra note 100 , at 513.

205. See Lochner v. New York, 198 U.S. 45 (1905) (overturning a New York law limiting the number of hours a baker could work in a week because the public health interest asserted by New York did not outweigh the individual's freedom to contract, which is protected by the Due Process clause of the Fourteenth Amendment).

206. Id. at 67.

207. See Jacobson, 197 U.S. 11 (1905); Lochner, 198 U.S. 45 (1905). The Court released the Jacobson opinion February 20, 1905 and released the Lochner opinion on April 17, 1905.

208. See Gostin, supra note 99, at 288. The author describes the Lochner court as "a politically conservative Court [that] struck down a great deal of social and economic regulation."

209. See Gostin, supra note 99, at 314 ("Since Roosevelt's New Deal, the Court has granted police power regulation a strong presumption of validity even if it interferes with economic and commercial life.").

210. See generally, Curtice, 209 F. at 589; Albert, 200 N.E. at 688.

211. See discussion supra Part IV.A. 


\section{Model a trans fat ban after New York City's ban}

Indiana should adopt a statewide trans fat ban that closely resembles New York City's ban. The New York City ban provides a good model that would allow the Indiana General Assembly members to craft comprehensive legislation. Initially, the ban should include a trial period, much like in New York City. $^{212}$ Allot restaurant owners and chefs time to adjust to the new rules without facing penalties, but make sure that health inspections include checks on trans fat use. ${ }^{213}$ This will encourage compliance without exposing Indiana to unnecessary lawsuits due to assessing penalties. The grace period should also include a statewide education campaign about trans fats, their dangers, why Indiana decided to ban trans fats from restaurants, and what Indiana residents should expect. $^{214}$ Education is especially crucial because Indiana currently lacks any substantive health information that comes from the local government. $^{215}$ Furthermore, education may also increase public support for the trans fat ban and thus reduce the risk of lawsuits. The grace period should not last longer than a year and the educational campaign about the dangers of trans fats should be adopted into regular health information produced by Indiana's state and local government institutions.

A legislative decision to enact the trans fat ban would have to be written to amend the Indiana Administrative Code. ${ }^{216}$ These amendments would include the definitions, procedures, limitations, and penalties related to the trans fat ban. The mandatory trans fat ban should expressly prohibit any foods that contain more than 0.5 grams of trans fat per serving from being "stored, distributed, held for service, used in preparation of any menu item or served in any food service establishment."217 It is important to define what it means for a food to contain trans fats because the FDA allows food manufacturers to include up to 0.5 grams of trans fats and still claim that there are zero grams of trans fats. ${ }^{218}$ Additionally, the trans fat ban should include requirements for food establishments to keep and store nutritional labels. ${ }^{219}$ Penalties for violat-

212. See N.Y. COMP. CodES R. \& REGS. tit. 24, \$ 81.08 (2007) ("In June 2005, the Department launched the Trans Fat Education Campaign. The campaign called on all NYC [food service establishments] to voluntarily remove [partially hydrogenated vegetable oil] from the foods they were serving.").

213. See The Regulation to Phase OUt Trans Fat, supra note 89 (explaining New York City's three month grace period to allow restaurants to comply with the trans fat ban).

214. See N.Y. COMP. CODES R. \& REGS. tit. 24, \$ 81.08 (2007) (The ban "was supported by extensive educational outreach to food suppliers, consumers and to every licensed restaurant in New York City.").

215. See supra discussion Part III.A.

216. 410 IND. ADMIN. CODE 7-24 (2004) ("Sanitary Standards for the Operation of Retail Food Establishments.").

217. N.Y. COMP. CODES R. \& REGS. tit. 24, § 81.08 (2007).

218. See Kassel, 359 U.S. at 520.

219. See N.Y. COMP. CODES R. \& REGS. tit. 24, § 81.08 (2007) ("Food service establishments and mobile food unit commissaries shall maintain on site the original labels for all food products."). 
ing the trans fat ban should also be detailed; however, the penalties may have to be included in a separate section of the Indiana Administrative Code. ${ }^{220}$

\section{CONCLUSION}

Enacting a trans fat ban statewide in Indiana is going to be met with opposition. Individuals who see the ban as a paternalistic form of government will criticize the ban for infringing on their constitutional rights, whereas, others will argue the Government is impeding on the free market. The criticisms should be listened to and not overlooked; however, it is important to remember that the State does have the legal authority to enact a trans fat ban. When debating a trans fat ban, Indiana legislators do not have to choose between improving the health of Hoosiers or avoiding the label of a "Nanny" state. Instead, the proper way to frame the debate is a choice between improving the health of Hoosiers or upholding a commercial interest to use a harmful product. Despite public resistance to public health regulations, Indiana should take the bold leap and enact the ban to take an active part in improving the health and welfare of Indiana citizens. Removing trans fats is not the cure-all remedy to our health problems, but rather a starting point for Indiana to take an active role in battling the epidemic of chronic disease. 
